\title{
Metacognitive Listening Strategies Used by Saudi EFL Medical Students
}

\author{
Eid Alhaisoni ${ }^{1}$ \\ ${ }^{1}$ Department of English Language, College of Arts, University of Ha'il, Saudi Arabia \\ Correspondence: Eid Alhaisoni, Department of English Language, College of Arts, University of Ha'il, Saudi \\ Arabia. E-mail: eid.alhaisoni@gmail.com
}

Received: December 20, 2016

Accepted: January 14, 2017 Online Published: January 16, 2017

doi: $10.5539 /$ elt.v10n2p114

URL: http://dx.doi.org/10.5539/elt.v10n2p114

\begin{abstract}
The present study investigated the metacognitive listening strategies among Saudi EFL medical students. The participants were 104 males and females, randomly selected to fill in the Metacognitive Awareness Listening Questionnaire (MALQ), developed and validated Vandergrift Goh, Mareschal, and Tafaghodtari (2006). The results revealed that participants use problem-solving and direct attention strategies more frequently than other metacognitive listening strategies. On the other hand, mental translation and personal knowledge strategies were reported to be the least used strategies. The pedagogical implications of these findings are discussed.
\end{abstract}

Keywords: metacognitive awareness, metacognitive listening strategies, listening comprehension, EFL

\section{Introduction}

Listening is an indispensable skill that develops faster than speaking and often affects the development of reading and writing abilities in learning a new language (Oxford, 1993; Scarcella \& Oxford, 1992). This is because one receives input through listening to instructions or explanations prior to responding orally or in writing. Acquiring listening skills is not an easy task since listeners are required to figure out the meaning from the oral input relying on their their prior knowledge of the world and of the target language (Byrnes, 1984; Nagle \& Sanders, 1986; Young, 1997) and to retrieve information from their long-term memory and make their own interpretations of the spoken passages (Mendelsohn, 1994; Murphy, 1985; Young, 1997). Vandergrift (2003) declares that listening is a complicated and active process of interpretation in which listeners try to match what they hear with their prior knowledge. However, for L2 learners this would be a complex process since their memory have limited capacity of the target language (Richards, 1983) hence they are required to employ various listening strategies. These strategies, which have been developed based on O'Malley and Chamot's (1990) learning strategies classification, and classified as cognitive, metacognitive, and socio-affective strategies, are steps taken to contribute learners' acquisition, storage, retrieval, and use of information. Metacognitive strategies are utilised by L2 learners to increase their comprehension and L2 retention, and include planning, monitoring, evaluating and problem-solving; cognitive strategies are employed by listeners to cope with the material they learn or to apply specific techniques, such as repeating, imagery, inferencing, deduction, note-taking, elaboration, and translation. Socio-affective strategies are used by L2 learners to cooperate with their classmates, to ask the teacher for more clarification, or to apply specific techniques to decrease anxiety (O’Malley, Chamot, \& Kupper, 1989; Vandergrift, 1997).

Listening skills have been neglected by teachers and researchers (Field, 2008; Oxford, 1993). Nunan (2002) argues that listening skills are treated as a secondary skill and as a means to an end, rather than an end in itself. According to Graham (2003), listening in a foreign language is a complex but underestimated skill. It was not until the 1960s, which witnessed emphasis on oral language skills, that listening was given a boost (Nunan, 2002: 238). As listening plays an indispensable role in the speaking skills development and meaningful mental representations in the target language, researchers are required to pay much attention to listening skill. Moreover, the learning style that a listener prefers to solve problems is closely related to the conscious actions taken by the individual (Ehrman et al., 2003; Flowerdew \& Miller 2005). The reason why the focus of this study is particularly on metacognitive listening strategies, rather than on any other type of strategy, is that this group is believed to play a vital role in facilitating language learning, for they 'oversee, regulate, or direct the language learning process' (Vandergrift, 1999: 170). 
Although listening strategies play a significant role in the development of foreign language proficiency, very limited studies have investigated the use of metacognitive listening strategies in the Saudi context. Therefore, this study aims to investigate the metacognitive listening strategies used by Saudi EFL medical students. As far as the researcher is able to ascertain, this is the first study of its kind to investigate Saudi medical students' use of learning strategies in general and listening strategies in particular.

\section{Literature Review}

\subsection{Metacognitive Strategies}

According to Flavell (1976) metacognition is a process in which a person is actively monitoring, controlling and arranging the cognitive process in order to attain cognitive goals. Metacognitive strategies, which reflect thinking about one's own thinking (Flavell, 1976), the individual's level of consciousness (Wenden, 1998), or the level of control over one's mental processes (Nelson, 1996), play a critical role in the cognitive processes of language as a means of communication. Flavell (1979) argues that metacognition includes both metacognitive knowledge and metacognitive experiences. The latter is defined as 'any conscious cognitive or affective experiences that accompany and pertain to any intellectual enterprise' (p. 906). Metacognitive experiences can activate strategies aimed at cognitive or metacognitive goals. Metacognitive knowledge, on the other hand, consists mainly of 'knowledge or beliefs about what factors or variables act and interact in what ways to affect the course and outcome of cognitive enterprises' (p. 907). Flavell identifies three major categories of metacognitive knowledge, which are person, strategy knowledge and task. Besides metacognitive knowledge and metacognitive experience, strategy use is identified by Vandergrift et al. (2006) as the third component of metacognition. This component 'builds on strategy knowledge,' yet it also includes 'awareness of when and how to use specific strategies' (Flavell, 2006: 89). In regard to these three components of metacognition, experience is 'an involuntary response,' whereas knowledge and strategy are 'amenable to instruction' (p. 101).

O'Malley and Chamot (1990) state that 'metacognitive strategies involve thinking about the learning process, planning for learning, monitoring the learning task, and evaluating how well one has learned' (p. 137). Therefore, these strategies have an executive function. They are considered a mental tool and a sign of successful learning that occupies the position of a seventh sense (Birjandi, Mirhassani, \& Abbasian, 2006). According to Harris (2003) metacognition is a guiding process to learning in which the learner is using strategies to plan, monitor and evaluate language use and language learning.

Cohen and Dörnyei (2002), cited in Altuwairesh (2016), state that metacognitive strategies refer to 'those processes which learners consciously use in order to supervise or manage their language learning,' which 'allow learners to control their own cognition by planning what they will do, checking how it is going and then evaluating how it went' (p. 181). Oxford (2001) says that this type of strategies helps learners 'manage themselves as learners, the general learning process, and specific learning tasks' (p. 167). Since metacognitive strategies are related to such essential variables in learning, i.e. the learner, learning in general and particular learning tasks, it becomes evident why researchers argue for the importance of investigating this type of strategy. Furthermore, investing classroom time in them enables language teachers to equip their students with 'empowering' tools (Anderson, 2002). Anderson (2002) elaborates on this point by stating that 'the use of metacognitive strategies ignites one's thinking and can lead to more profound learning and improved performance, especially among learners who are struggling' (p. 2), all of which are aims of any language teacher and learner.

Anderson (2002) argues that metacognition can be grouped into five major components, including preparing and planning for learning, selecting and using learning strategies, monitoring strategy use, orchestrating various strategies and evaluating strategy use and learning. This relates to some extent to the declarative and procedural knowledge involved in metacognition, mentioned by Chamot (2005), in which planning, monitoring and evaluating form the procedural knowledge, whereas selecting, using and orchestrating strategies form part of the declarative knowledge. Vandergrift et al. (2006) believe that listening metacognitive awareness comprises five factors which are planning evaluation, problem solving, translation, direct attention and personal knowledge.

\subsection{Previous Studies on Metacognitive Listening Strategies}

One of the earliest studies conducted in the area of second language listening strategies was done by O'Malley, Chamot and Küpper (1989). The researchers used think-aloud protocols to identify the listening strategies that 11 intermediate level high-school students used when performing a listening task. The study aimed to compare effective and ineffective listeners in order to find out any differences in the use of learning strategies that existed between the two groups of learners. Results demonstrate that whatever strategy any student uses varies depending on the phase in the listening comprehension process. The students used selective attention and 
self-monitoring in the perceptual processing stage, grouping and inferencing in the parsing stage, and elaboration in the utilisation stage. The study also found that effective listeners use strategies more successfully than their less effective peers.

Wang (2002) conducted a study to investigate the listening comprehension strategies employed by EFL learners in Taiwan. The results revealed that metacognitive strategies are used frequently in the English listening process. The findings also indicated that EFL learners reported to use the self-management strategies and the monitoring strategy in metacognitive strategies to facilitate their listening comprehension. Bidabadi and Yamat (2013) found in their study that EFL learners used directed knowledge strategies more frequently than other listening strategies. This indicates that it was necessary that EFL learners focus on the listening texts, and that this kind of strategy could help them achieve listening comprehension.

Vandergrift (2003) conducted a study which aimed to explore the type of strategies used and the relationship between listening strategy use and listening proficiency. The participants of the study were thirty-six junior high school students of French in Canada. Results indicate that students used all types of metacognitive strategies recognised in the literature, including: planning strategies, monitoring strategies and problem identification strategies. The only type of strategy not used was evaluation strategies. The study also revealed that the high proficient listeners used metacognitive strategies more frequently than the low proficient listeners. Thus, the study suggests that in order to enhance L2 listening performance, it is recommended to teach low proficient listeners how to use metacognitive strategies.

Altuwairesh (2016) investigated the metacognitive listening strategies used by Saudi EFL female students when listening to texts in English. Two main research questions were explored in the study: (1) which of the five major types of metacognitive strategies do the participants use most when listening to English texts? and (2) what are the metacognitive listening strategies used most by the target group when listening to English texts? The Metacognitive Awareness Listening Questionnaire was used to arrive at answers to the two research questions. The participants were 82 students from the same cohort. Results reveal that the participants reported using problem-solving and directed attention strategies more frequently than the other metacognitive listening strategies; mental translation and personal knowledge strategies are the least used by the participants. The results give insight into the metacognitive listening strategies used by effective L2 listeners, with ample evidence provided from the literature available on the subject. Results of this study also demonstrate that many L2 learners do in fact perceive listening as difficult, thus, investing classroom time in developing learners' strategies is worthwhile.

\section{Methods}

\subsection{Subjects}

The subjects of this study included 104 male and female sixth-year medical students at the College of Medicine at University of Ha'il in Saudi Arabia. They enrolled for the spring term, 2015-2016. They are in their last year at the college and then they will be enrolled in an internship for one year to prepare them to start practicing medicine as general practitioners (GP). The reason behind targeting year-six students is because they have been exposed to the English language at the college for a minimum of six years, since the medium of instruction at the college of medicine is English and they have therefore gained experience in using language learning strategies, including listening strategies. Their age ranged between 23-27 years old. They were selected randomly to participate in the study and did so of their own free will.

\subsection{Instruments}

According to Vandergrift et al. (2006), among the various procedures used to investigate learners' metacognitive knowledge about listening, the most commonly used are diaries, interviews and questionnaires (p. 436). However, Oxford (1996) states that "questionnaires are among the most efficient and comprehensive ways to assess frequency of language learning strategy use" (p. 25). Questionnaires have been widely used in studies on listening strategies like Goh (2002), Vandergrift (2005), and Vogely (1995). Hence, the instrument used in this study was the Metacognitive Awareness Listening Questionnaire (MALQ) developed and validated by Vandergrift et al. (2006). According to Goh et al. (2013), this questionnaire is based on research and theories concerning L2 listening, specifically on Flavell's (1979) proposals about metacognition. It elicits an awareness of five distinct strategies: Personal knowledge, mental translation, direct attention, problem-solving, planning and evaluation. In other words, the questionnaire seeks information about the perception that students have of their use of strategies when engaged in a listening task, and also asks for information related to the personal knowledge and how confident they feel about listening in the target language. In more specific terms, directed attention strategies refer to the students' ability to concentrate on a specific task, mental translation strategies 
help students to translate the information heard in the L2 into their first language, planning and evaluation strategies are meant to guide students to prepare before listening and to evaluate their performance after listening, and problem-solving strategies help students to make inferences when they do not understand a certain word. Finally, personal knowledge shows students' self-confidence in L2 listening tasks. The MALQ has 21 items. Students have to respond to the 21 statements by rating their responses on a six-point Likert scale. According to Vandergrift et al. (2006), they chose a scale without a neutral point so that respondents could not hedge. The questionnaire was translated into Arabic in order to facilitate the students' understanding of the statements when soliciting the information. The questionnaire was administered by the researcher during a regular class period. The students were told that there were no right or wrong answers to the questions and their responses would be used for research purposes only. They were also informed that they have the right not to participate.

The questionnaire items were analysed using SPSS 19 to calculate descriptive statistics (for example frequency counts and percentages). The internal reliability of the questionnaire calculated by Cronbach's alpha was at $\alpha$ $=.80$.

\section{Results and discussion}

Table1. Distribution of mean scores on MALQ and its subscales $(n=104)$

\begin{tabular}{lll}
\hline Statement & Mean & SD \\
\hline Problem-solving strategies & 4.92 & .985 \\
Direct attention strategies & 4.20 & .821 \\
Planning and evaluation & 3.98 & .785 \\
Mental translation & 3.40 & .824 \\
Personal knowledge & 3.32 & .991 \\
\hline
\end{tabular}

Table 1 above includes the mean and standard deviation for 104 Saudi EFL medical students who participated in this study using MALQ and its subsections. The results show that the mean of the MALQ subscale ranges from 3.32 to 4.92 , and the average score is 4.38 which indicates that the use of metacognitive listening strategies for Saudi EFL medical students was average, as each item had been measured on a 6-point Likert scale. The results also reveal that problem-solving strategies were reported by the subjects as being used more than other types of metacognitive listening strategies with mean frequency rating of 4.92 .

Table 2. Post hoc paired comparison following repeated measures ANOVA showing the $p$ value of differences in use for different listening strategies

\begin{tabular}{llllll}
\hline MLS & PROB & DAS & PES & MTS & PKS \\
\hline PROB & & $\mathrm{p}=.001$ & & \\
DAS & & $\mathrm{p}=.120$ & $\mathrm{p}=.001$ & $\mathrm{p}=.001$ \\
PES & & & $\mathrm{p}=.112$ & \\
MTS & & & $\mathrm{p}=.091$ & $\mathrm{P}=.124$ \\
\hline
\end{tabular}

These differences were corroborated through one-way repeated measures ANOVA which showed significant differences in the use of types of metacognitive listening strategies by all the subjects $(F=117.649, p=.001)$. To know where the difference lies between the five types of strategies, Bonferroni adjusted multiple comparisons were performed. The results show that problem-solving strategies are used significantly more than all the other types $(p=.001)$. Furthermore, direct attention strategies are used significantly more often than $(p=.001)$ mental translation and personal knowledge strategies which, in turn, are the least frequently used metacognitive listening strategies in the study. On the other hand, no significant differences were found between other types. This result agrees with the other studies reviewed in the literature which found that problem-solving strategies are used more frequently than other types of metacognitive listening strategies (Chamot \& Küpper, 1989; Graham, 2003; Vandergrift et al., 2006; Ratebi, 2013; Altuwairesh, 2016). This result indicates that Saudi EFL medical students resort to their repertoire of vocabulary and the general idea of the text to deduce the meaning of 
unknown words, use their experience and general knowledge in interpreting the text, adjust their interpretation upon realising that it is not correct, monitor the accuracy of the inferences for congruency with developing interpretation, and compare the developing interpretation with their knowledge of the topic (Vandergrift et al., 2006). In her study concerning the use of metacognitive listening strategies by Saudi EFL university students, Altuwairesh (2016) found that the subjects reported the use of problem-solving strategies more than other types of metacognitive listening strategies. According to Vandergrift et al. (2006), problem-solving 'represents a group of strategies used by listeners to inference... and to monitor these inferences' (p. 450). Chamot and Küpper (1989), cited in Altuwairesh (2016), found that effective listeners reported using comprehension monitoring and problem identification strategies more frequently than ineffective ones. Both types of strategies are related to the factor of problem-solving in the MALQ, for inferencing is the way students deal with words or ideas that might cause them listening comprehension difficulties. Vandergrift (1997) conducted a study to investigate the listening strategies used by French L2 listeners. He found that 'comprehension monitoring appears to be the metacognitive strategy reported most often' (p. 396). Moreover, Berne (2004) reviewed the findings of a number of studies that were concerned with differences between more and less proficient listeners. In regards to problem-solving strategies, she concluded that more proficient listeners are able to 'guess the meanings of words' and 'relate what they hear to previous experiences' whereas less proficient listeners 'make fewer inferences' and 'do not verify their assumptions' (p. 525).

Regarding the individual strategies which come under problem-solving strategies, all six strategies belonging to this factor have been reported among the most frequently used by the subjects. The most frequently used strategy in this factor is 'the use of known words to guess the meanings of unknown ones' with a mean of 5.21 and SD of .982, followed by 'using the general idea of the text to guess the meaning of unknown words' with a mean of 4.91 and SD of .864 $(\mathrm{M}=3.35)$. The remaining four strategies in this group did not show any significant means, which indicates that a large number of the target group did not favour the use of these strategies.

Direct attention, which represents actions undertaken by listeners regarding concentration and staying on task, such as focusing harder when having difficulty understanding or getting back on track when losing concentration (Rost, 2002), ranked second with a mean frequency rating of 4.20. Vandergrift et al. (2006) define direct attention as 'strategies that listeners use to concentrate and stay on the task' (p. 451). This result agrees with previous studies which found that direct attention strategies are used frequently by students. Ratebi (2013) found that his Iranian university students majoring in English reported a frequent use of direct attention strategies, which came second after problem-solving strategies. Moreover, in a recent study in a Saudi context, Altuwairesh (2016) found that Saudi EFL female students reported a high use of this factor in comparison to other factors.

Under this factor belong four individual strategies, of which three have been reported to be frequently used by the subjects in this study. The only strategy which was not reported to be commonly used by the subjects is 'giving up and stopping listening when having difficulty of understanding'. Vogely (1995) conducted a study and found that more than half the participants reported using the strategy of recovering concentration upon losing it, which means, according to the researcher, that they are active listeners (p. 47). The study also indicated that giving up listening when having a problem is not favoured by students (Vogely, 1995). This result also was reported by other researchers (Li, 2013; Ratebi, 2013; Altuwairesh, 2016).

Planning and evaluation strategies are the third most frequent of the metacognitive listening strategies used by the subject in the current study with a mean frequency rate of 3.98. Vandergrift (2003) found that his participants reported high use of planning strategies. Goh and Taib (2006) also found similar results. (Vandergrift et al., 2006:450) argue that "the planning and evaluation factor represents the strategies listeners use to prepare themselves for listening, and to evaluate the results of their listening efforts". These items include strategies that related to setting a plan before listening, recalling texts similar to the one in hand, keeping a goal in mind during listening, periodically questioning one's degree of satisfaction with the level of understanding while listening, and finally after listening, reflecting on one's listening efforts and thinking of ways to make listening better next time. It should be mentioned here that out of these six strategies, three strategies were reported among the most frequently used by the subjects.

Goh (2002) says, unlike monitoring strategies, planning and evaluation do not hamper listening and they consequently have a significant impact on overall listening. Further, the presence of planning and evaluation strategies is an indication that 'responsibility for learning shifts from the teacher to the student' (Vandergrift, 2002:571). Stepping back from real-time listening to reflect on the listening process helps learners 'understand and change learning behaviours'. As Anderson (2008) explains 'metacognition results in critical but healthy reflection and evaluation of thinking that may result in making specific changes in how learning is managed, and in the strategies chosen for this purpose' (p. 99). He further comments on planning strategies by saying that 
'taking time to prepare for learning and plan what needs to be accomplished makes a major difference in learning' (p. 100).

The least frequently used strategy was 'personal knowledge' with s mean frequency rating of 3.32. It includes items that assess the perceived difficulty of listening compared with the three other language skills, learners' linguistic confidence in second or foreign language listening, and the anxiety level experienced in second or foreign language listening (Sparks \& Ganschow, 2001). It shows that Saudi EFL medical students have a low level of confidence and self-efficacy in listening comprehension and they perceive listening skills to be harder than other skills. Maybe it can be said that because Saudi EFL students consider listening as a difficult task to perform, they concentrate with difficulty and try to do their best in this regard.

The second least used strategy was 'mental translation' with a mean frequency rating of 3.40. This factor includes strategies that should be avoided by L2 learners in order to become skillful listeners, and thus, a lower mean score is desirable. The three items this factor represents 'all tap the online mental translation strategy', which is 'an inefficient approach to listening comprehension' (Vandergrift et al., 2006: 450). Graham and Macaro (2008) also explain that translation is a type of bottom-up strategy which is 'the mark of ineffective listeners' (p. 749). Furthermore, Vandergrift and Tafaghodtari (2010) believe that for them to be successful L2 listeners, students are required to overcome the compulsion to translate word for word, which they may face while listening. Vandergrift (2003) says that less translation is a strategy employed by more skilled listeners (p. 458). Translation, he says, 'involves only surface mapping between languages [and] generally fails to activate conceptual processes' (Vandergrift, 2003, p. 486).

\section{Conclusion}

This study explored the metacognitive listening strategies used by Saudi EFL medical students. The findings reveal that the students reported using problem-solving and direct attention strategies more frequently than other strategies. The results also show that problem-solving strategies are used significantly more than all the other types. Furthermore, direct attention strategies are used significantly more often than mental translation and personal knowledge strategies which, in turn, are the least frequently used metacognitive listening strategies in the study. Based on these findings, it is important that EFL teachers help their students to use listening strategies such as mental translation and personal knowledge. Furthermore, EFL students should be encouraged to avoid word-for-word or key-word translation while listening. Literal translation, a commonly used practice in EFL classrooms, is probably attributed to students' attempts to compensate for the lack of exposure to L2 in authentic communication. Calis and Dikilitas (2012), for example, found that L2 learners with positive attitudes toward translation have believed translation was helpful in memorising L2 vocabulary. This, in turn, reflects a focus on form, rather than on meaning, in interaction mediated by $\mathrm{L} 2$.

The findings of this study can convince language teachers to pay more attention to listening strategy instruction. Vandergrift et al. (2006) state that 'research on the effects of metacognitive instruction has provided preliminary evidence that performance, confidence, and motivation can be enhanced through classroom instruction (p. 436). However, Macaro, Graham, and Vanderplank (2007) say that 'strategy instruction in the skill of listening is still very much in its infancy' (p. 185). The aim of the strategy training is to increase learners' awareness about making decisions concerning their own strategy use to tackle language tasks. Strategy training implies that the learners can take control of their own learning by planning a goal, monitoring the processes, and evaluating the learning outcomes. This implies that nurturing learners' metacognition is the key to successful learning. Wenden (2002), Goh (2002), and Vandergrift (1997) emphasise that learners' metacognitive processing is closely related to effective learning and is applicable to all learning contexts.

To sum up, Berne (2004), cited in Altuwairesh (2016), states that 'listening comprehension strategies have been and continue to be a very fruitful area for researchers to explore' (p. 52). Nevertheless, 'whilst there is a considerable body of literature exploring listening strategy use, the literature related to strategy instruction is more sparse, although there is an emerging research agenda' (Macaro, Graham, \& Vanderplank, 2007, p. 165). Even though listening is now generally believed to play a vital role in second language acquisition and the facilitation of language learning, it is still considered 'a young field that merits greater research attention" (Vandergrift, 2003, p. 464).

\section{References}

Altuwairesh, N. (2016). EFL Saudi Undergraduate Students' Use of Metacognitive Listening Strategies. Arab World English Journal, 7(1), 78-93. https://doi.org/10.2139/ssrn.2803998 
Anderson, N. J. (2002). The role of metacognition in second language teaching and learning. ERIC Digest, April 2002. Washington, DC: Centre for Applied Linguistics.

Berne, J. (2004). Listening comprehension strategies: A review of the literature. Foreign Language Annals, 37(4), 521-531. https://doi.org/10.1111/j.1944-9720.2004.tb02419.x

Birjandi, P., Mirhassani, A., \& Abbasian, G. (2006). Setting-based metacognitive strategy use. The revised two-factor study process questionnaire: R-SPQ-2Fb. Journal of Faculty of Letters and Humanities Psychology, 49(198), 39-87.

Buck, G. (2001). Assessing listening. Cambridge: Cambridge University Press. https://doi.org/10.1017/CBO9780511732959

Byrnes, H. (1984). The role of listening comprehension: A theoretical base. Foreign Language Annals, 17(4), 317-329. https://doi.org/10.1111/j.1944-9720.1984.tb03235.x

Calis, E., \& Dikilitas, K. (2012). The use of translation in EFL classes as L2 learning practice. Procedia Social and Behavioral Sciences, 46, 79-84. https://doi.org/10.1016/j.sbspro.2012.06.389

Chamot, A. (2005). Language learning strategy instruction: Current issues and research. Annual Review of Applied Linguistics, 25, 112-130. https://doi.org/10.1017/s0267190505000061

Cohen, A., \& Dörnyei, Z. (2002). Focus on the language learner: Motivation, styles and strategies. In N. Schmitt (Ed.), An introduction to applied linguistics (pp. 170-190). London: Arnold.

Ehrman, M., Leaver, B. L., \& Oxford, R. L. (2003). A brief overview of individual differences in second language learning. System, 31, 313-330. https://doi.org/10.1016/S0346-251X(03)00045-9

Field, J. (2004). An insight into listeners' problems: Too much bottom-up or too much top-down? System, 32, 363-377. https://doi.org/10.1016/j.system.2004.05.002

Field, J. (2008). Listening in the language classroom. Cambridge: Cambridge University Press.

Flavell, J. H. (1976). Metacognitive aspects of problem solving. In L. B. Resnick (Ed.), The nature of intelligence. Hillsdale, NJ: Erlbaum.

Flavell, J. H. (1979). Metacognition and cognitive monitoring: A new area of cognitive-developmental inquiry. American Psychologist, 34, 906-911. https://doi.org/10.1037/0003-066X.34.10.906

Flowerdew, J., \& Miller, L. (2005). Second language listening: Theory and practice. New York: Cambridge University Press. https://doi.org/10.1017/CBO9780511667244

Goh, C. (2002). Exploring listening comprehension tactics and their interaction patterns. System, 30, 185-206. https://doi.org/10.1016/S0346-251X(02)00004-0

Goh, C. (2008). Metacognitive instruction for second language listening development: Theory, practice and research implications. RELC, 39(2), 188-213. https://doi.org/10.1177/0033688208092184

Goh, C., \& Taib, Y. (2006). Metacognitive instruction in listening for young learners. ELT Journal, 60(3), 222-232. https://doi.org/10.1093/elt/ccl002

Goh, C. M., \& Hu, G. W. (2013). Exploring the relationship between metacognitive awareness and listening performance with questionnaire data. Retrieved August 2016, from http://www.tandfonline.com/doi/full/10.1080/09658416.2013.769558\#.UsZ8FvQW1MA

Graham, S. (2003). Learner strategies and advanced level listening comprehension. Language Learning Journal, 28, 64-69. https://doi.org/10.1080/09571730385200221

Graham, S., \& Macaro, E. (2008). Strategy instruction in listening for lower-intermediate learners of French. Language Learning, 58(4), 747-783. https://doi.org/10.1111/j.1467-9922.2008.00478.x

Graham, S., Santos, D., \& Vanderplank, R. (2008). Listening comprehension and strategy use: A longitudinal exploration. System, 36, 52-68. https://doi.org/10.1016/j.system.2007.11.001

Harris, V. (2003). Adapting classroom-based strategy instruction to a distance learning context. TESOL Internet Journal, 7(20).

Li, W. (2013). A study of metacognitive awareness of non-English majors in L2 listening. Journal of Language Teaching and Research, 4(3), 504-510. https://doi.org/10.4304/j1tr.4.3.504-510

Lynch, T. (2006). Academic listening: Marrying top and bottom. In E. Usó-Juan, \& A. Martínez-Flor (Eds.). Current trends in the development and teaching of the four language skills (pp. 91-110). Berlin: Mouton de 
Gruyter. https://doi.org/10.1515/9783110197778.2.91

Lynch, T., \& Mendelsohn, D. (2002). Listening. In N. Schmitt (Ed.), An introduction to applied linguistics (pp. 193-210). London: Arnold.

Macaro, E. (2001). Learning strategies in foreign and second language classrooms. London: Continuum.

Macaro, E., Graham, S., \& Vanderplank, R. (2007). A review of listening strategies: Focus on sources of knowledge and on success. In A. Cohen \& E. Macaro (Eds.), Language learner strategies (pp. 165-185). Oxford: Oxford University Press.

Nagle, S. J., \& Sanders, S. L. (1986). Comprehension theory and second language pedagogy. TESOL Quarterly, 20(1), 9-26. https://doi.org/10.2307/3586386

Nelson, T. (1996). Consciousness and metacognition. American Psychologist, 51, 102-116. https://doi.org/10.1037/0003-066X.51.2.102

Nunan, D. (2002). Listening in language learning. In J. Richards \& W. Renandya (Eds.), Methodology in language teaching: An anthology of current practice (pp. 238-241). Cambridge: Cambridge University Press. https://doi.org/10.1017/CBO9780511667190.032

O’Bryan, A., \& Hegelheimer, V. (2009). Using a mixed methods approach to explore strategies, metacognitive awareness, and the effects of task design on listening development. Canadian Journal of Applied Linguistics, 12(1), 9-33.

O’Malley, J., \& Chamot, M. (1990). Learning strategies in second language acquisition. Cambridge: Cambridge University Press. https://doi.org/10.1017/CBO9781139524490

O’Malley, J., Chamot, M., \& Küpper, L. (1989). Listening comprehension strategies in second language acquisition. Applied Linguistics, 10(4), 418-437. https://doi.org/10.1093/applin/10.4.418

O’Malley, M. J., \& Chamot, A. U. (1990). Learning strategies in second language acquisition. Cambridge: Cambridge University Press. https://doi.org/10.1017/CBO9781139524490

Oxford, R. L. (1990). Language learning strategies: What every teacher should know. New York: Newbury House Harper Collins.

Oxford, R. L. (1993). Research update on teaching L2 listening. System, 21(2), 205-211. https://doi.org/10.1016/0346-251X(93)90042-F

Oxford, R. L. (1996). Employing a questionnaire to assess the use of language learning strategies. Applied Language Learning, 7(1), 25-45.

Oxford, R. L. (2001). Language learning strategies. In R. Carter, \& D. Nunan (Eds.), The Cambridge guide to teaching English to speakers of other languages (pp. 166-172). Cambridge: Cambridge University Press. https://doi.org/10.1017/CBO9780511667206.025

Ratebi, Z. (2013). Use of Metacognitive Strategies in Listening Comprehension by Iranian University Students Majoring in English: A Comparison between High and Low Proficient Listeners. Journal of Studies in Education, 3(1), 140-154. https://doi.org/10.5296/jse.v3i1.2969

Richards, J. C. (1983). Listening comprehension: Approach, design, procedure. TESOL Quarterly, 17(2), 219-240. https://doi.org/10.2307/3586651

Richards, J., \& Renandya, W. (Eds.). (2002). Methodology in language teaching: An anthology of current practice. Cambridge: Cambridge University Press. https://doi.org/10.1017/CBO9780511667190

Rost, M. (2001). Listening. In R. Carter \& D. Nunan (Eds.), The Cambridge guide to teaching English to speakers of other languages (pp. 7-13). Cambridge: Cambridge University Press. https://doi.org/10.1017/CBO9780511667206.002

Rost, M. (2002). Teaching and researching listening. Harlow: Longman.

Rost, M. (2006). Areas of research that influence L2 listening instruction. In E. Usó-Juan, \& A. Martínez-Flor (Eds.), Current trends in the development and teaching of the four language skills (pp. 47-74). Berlin: Mouton de Gruyter. https://doi.org/10.1515/9783110197778.2.47

Scarcella, R. C., \& Oxford. R. L. (1992). The tapestry of language learning: The individual in the communicative classroom. Boston, MA: Heinle \& Heinle.

Sparks, R., \& Ganschow, L. (2001). Aptitude for learning a foreign language. Annual Review of Applied 
Linguistics, 21, 90-112. https://doi.org/10.1017/s026719050100006x

Vandergrift, L. (1996). Listening strategies of Core French high school students. Canadian Modern Language Review, 52(2), 200-223.

Vandergrift, L. (1997). The strategies of second language (French) listeners: A descriptive study. Foreign Language Annals, 30, 387-409. https://doi.org/10.1111/j.1944-9720.1997.tb02362.x

Vandergrift, L. (1999). Facilitating second language listening comprehension: Acquiring successful strategies. ELT Journal, 53(3), 168-176. https://doi.org/10.1093/elt/53.3.168

Vandergrift, L. (2003). Orchestrating strategy use: toward a model of the skilled second language listener. Language learning, 53(3), 463-496. https://doi.org/10.1111/1467-9922.00232

Vandergrift, L. (2004). Listening to learn or learning to listen? Annual Review of Applied Linguistics, 24, 3-25. https://doi.org/10.1017/S0267190504000017

Vandergrift, L. (2005). Relationships among motivation orientations, metacognitive awareness and proficiency in L2 listening. Applied Linguistics, 26(1), 70-89. https://doi.org/10.1093/applin/amh039

Vandergrift, L. (2007). Recent developments in second and foreign language listening comprehension research. Language Teaching, 40, 191-210. https://doi.org/10.1017/S0261444807004338

Vandergrift, L., Goh, C., Mareschal, C., \& Tafaghodtari, M. (2006). The metacognitive listening awareness questionnaire: Development and validation. Language Learning, 56(3), 431-462. https://doi.org/10.1111/j.1467-9922.2006.00373.x

Vandergrift, L., \& Tafaghodtari, M. (2010). Teaching L2 learners how to listen does make a difference: An empirical study. Language Learning, 60(2), 470-497. https://doi.org/10.1111/j.1467-9922.2009.00559.x

Vogely, A. (1995). Perceived strategy use during performance on three authentic listening comprehension tasks. The Modern Language Journal, 79(1), 41-56. https://doi.org/10.1111/j.1540-4781.1995.tb05414.x

Wenden, A. L. (1998). Metacognitive knowledge and language learning. Applied Linguistics, 19, 515-537. https://doi.org/10.1093/applin/19.4.515

Young, M. Y. C. (1997). A serial ordering of listening comprehension strategies used by advanced ESL learners in Hong Kong. Asian Journal of English Language Teaching, 1, 35-53.

\section{Copyrights}

Copyright for this article is retained by the author(s), with first publication rights granted to the journal.

This is an open-access article distributed under the terms and conditions of the Creative Commons Attribution license (http://creativecommons.org/licenses/by/4.0/). 